\title{
EFEKTIVITAS PARENTING ORANG TUA DALAM MENCEGAH PENGGUNAAN NARKOBA BAGI REMAJA PUTRA DAN PUTRI
}

\author{
Grido Handoko Sriyono ${ }^{1)}$, Yosef Wijoyo ${ }^{2)}$ \\ ${ }_{1,2}$ Program Studi S2 Farmasi, Universitas Sanata Dharma,Yogyakarta, Indonesia \\ email: gridoprob@gmail.com
}

\begin{abstract}
Abstrak
Penyalahgunaan narkoba di kalangan remaja sangat memprihatinkan terutama bagi remaja putra. Tujuan penelitian ini adalah mengetahui tipe parenting orang tua yang efektif untuk mencegah penyalahgunaan narkoba pada remaja. Penelitian ini adalah penelitian komparatif yang melibatkan remaja sebagai subyek penelitian yang ditentukan secara purposive sebanyak 80 subyek remaja putra dan 80 subyek remaja putri. Pengumpulan data menggunakan kuesioner, selanjutnya diolah dengan aplikasi Anova. Hasil analisis $\rho=0,022$ bermakna i $<0,05$ yang menunjukkan ada perbedaan upaya pencegahan narkoba yang berkaitan dengan parenting orang tua (authoritative, autoritarian dan permissive) bagi remaja putra dan putri. Rekomendasi kepada orang tua agar dapat memberikan layanan authoritative parenting yang lebih efektif kepada remaja karena masa ini adalah dimana remaja masih mencari identitas dirinya.
\end{abstract}

Kata kunci: parenting, orang tua, remaja, pencegahan narkoba

\begin{abstract}
Drug abuse among teenagers is a major concern, especially for young men. The purpose of this study was to figure out the type of effective parenting in preventing drug abuse in adolescents. This study is a comparative study involving adolescents as research subjects which were determined purposively with a total of 80 male subjects and 80 female subjects. Collecting data used a questionnaire, then processed with the Anova application. The results of the analysis $=0.022$, which means i $<<0.05$, which indicates that there are differences in drug prevention efforts related to parenting (authoritative, authoritarian and permissive) for young boys and girls. Recommendations to parents to be able to provide more effective authoritative parenting services to adolescents because this period is where adolescents are still looking for their identity.
\end{abstract}

Keywords: parenting, parents, adolescents, drug prevention

\section{PENDAHULUAN}

Penyalahgunaan narkoba oleh kaum remaja saat ini di Indonesia pada kondisi yang sangat mengkhawatirkan. Problem penyalahgunaan narkoba di negara ini mengarah kepada kemerosotan perilaku sosial remaja, karena grup besar pengguna narkoba adalah kaum milenial sebagai generasi masa depan negara Indonesia. Banyak bukti data bahwa penambahan jumlah pengguna narkoba sangat meningkat, lebih dari 200 juta remaja di seluruh negara pernah mengkonsumsi narkoba (Rabinowitz JA, Drabick DA, Reynolds MD, Clark DB, 2016).

Zat narkoba bisa dalam bentuk padat, cair maupun gas. Bila zat tersebut dimasukkan ke dalam tubuh dapat mengubah fungsi tubuh secara fisik dan psikis. Bahaya narkoba pada tiap orang sangat dipengaruhi oleh jenis narkoba yang digunakan dan penggunanya (Badan Narkotika Nasional, 2017). Zat narkoba masuk ke peredaran darah otak bertemu dengan reseptor spesifik tepat berada di neuron terjadi ikatan maka muncul efek. Contoh ikatannya seperti ikatan neurotransmitter (endorfin) yang bisa mengurangi impuls nyeri. Seperti halnya neurotransmiter, zat ini bisa menaikkan (stimulan SSP) atau menekan (depresan SSP) transfer impuls antar neuron di otak. Pada halusinogen, zat ini tidak meluruskan transfer impuls antar neuron dan juga disinyalir berefek langsung pada 'titik nikmat' (pleasure centres) pada otak biasa disebut dengan 'euphoria sesaat', sehingga bisa menciptakan kondisi rasa nuansa yang sangat menyenangkan dan ini merupakan efek berbagai macam narkoba dan tidak tergantung 
pada dosis tertentu. Zat narkoba adalah racun, karena efeknya berbahaya pada susunan syaraf pusat, dengan memacu atau menghambat reseptor, neurotransmiter, ataupun neuron yang ada di susunan syaraf pusat, tergantung jenis narkobanya. Jiwa menjadi riang (euphoric) sesaat, lalu terpacu (stimulated), namun kemudian menjadi tertekan (depressed) sehingga menimbulkan rasa letih dan lesu.

Pada kondisi normal, bila seseorang mengingat sesuatu, pikirannya bekerja sangat cepat untuk memunculkan informasi dari gambargambar yang telah tersimpan di memori. Tetapi karena narkoba, kondisi menjadi lesu sehingga mengaburkan gambar-gambar yang tersimpan, pada akhirnya informasi arsip gambarnya kabur dan berantakan. Narkoba menyebabkan seseorang jadi lamban, apatis, bodoh dan gagal. Narkoba tidak membuat bahagia, tetapi menghancurkan seluruh kebahagiaan, harapan dan keceriaan. Zat berbahaya ini menyebabkan lingkaran setan yang merusak jiwa yang bisa mengarah pada ganggguan jiwa sampai ke sakit jiwa (Sweeney CT, Sembower MA, Ertischek MD, Shiffman S, 2013).

Susunan syaraf pusat adalah pengendali sentral semua organ tubuh, bila narkoba masuk ke otak berarti SSP berada dalam cengkraman narkoba yang akan menyebabkan kekacauan pada semua sistem organ tubuh terutama sistem syaraf, sistem pernafasan, kardiovaskuler, pencernaan, urinaria dan sistem imun sehingga mudah sakit, sulit berpikir, depresi, respirasi, mual, gastritis, disorientasi, depresi, gangguan tidur, cemas berat, kecurigaan, ketegangan otot, rahang mengatup tanpa disengaja, penglihatan kabur, keletihan, kedinginan, gangguan memori, gangguan berfikir, kehilangan kontrol diri, halusinasi, stres berulang, depresi berat dan bunuh diri (Matejevic M, Jovanovic D, 2014). Efek jangka panjang adalah: dehidrasi hebat, ganggguan regulasi panas tubuh, kejang, kerusakan otak yang menetap, kerusakan hati, peningkatan tekanan darah, pecahnya pembuluh darah di retina mata, pecahnya pembuluh darah, stroke, gagal ginjal, gangguan irama jantung, gagal jantung dan kematian. Narkoba begitu besar bahayanya sehingga menimbulkan banyak masalah, hal ini juga mengarah pada kondisi masalah lingkungan dan sosial (Anisah, 2011).

Problematika kondisi sosial ini sedang menggelisahkan semua lapisan masyarakat sebab resiko bahaya narkoba bisa mengarah pada fisik dan psikis penggunanya. Pengguna barang haram oleh kaum remaja bisa berakibat pada masalah yang mengganggu respon reaksi, pemikiran, memori, pembelajaran, kreativitas, pengendali diri. Riset Adpriyadi \& Sudarto (2018) membuktikan bahwa penggunaan zat haram ini bisa mengakibatkan penurunan pada nilai pendidikan, ikatan persaudaraan menjadi buruk, pertengkaran bertambah dan perilaku merusak serta bertambahnya kasus kecelakaan lalu lintas.

Banyak kejadian masalah sosial masyarakat, problem sosial keluarga dan kisruhnya lingkungan sosial remaja dikarenakan para remaja menyalahgunakan narkoba. Maka dari itu penyalahgunaan narkoba oleh remaja harus dicegah. Orang tua bertanggung jawab terhadap parenting kepada anak karena hal ini merupakan wujud dari hak anak. Orang tua mempunyai kewajiban melakukan perlindungan, memberikan pendidikan dasar kepada semua anaknya. Dimulai dari lingkungan keluarga karena merupakan kondisi lingkungan yang sangat penting untuk terbentuknya karakter dan kepribadian anak. Anak bisa mulai belajar dari lingkungan keluarga yang bisa dijadikan modal anak kelak bila anak sudah menghadapi lingkungan di luar dan berinteraksi dengan orang di luar lingkungan keluarga (Anisah, 2011).

Menurut Abdullah (2015) parenting adalah suatu tindakan terbaik yang bisa dilakukan orang tua untuk membimbing anaknya dalam mewujudkan upaya pertanggungjawaban pada anaknya. Semua tindakan orang tua tersebut adalah wujud pertanggungjawaban primer. Jenis parenting yang biasa dilakukan oleh orang tua terdiri dari: 1) Authoritarian parenting, 2) Authoritative parenting dan 3) Permissive parenting.

Keterkaitan antara anak dengan orang tua berlangsung sepanjang usia dan secara terus menerus, sehingga keduanya memahami karakter masing-masing. Secara terus-menerus berikatan dengan keluarga dalam waktu yang tidak sebentar, memungkinkan anak mendapatkan gambaran bagaimana orang tua bersikap. Anak bisa mempersepsikan orang tuanya sebaliknya orang tua juga bisa mempersepsikan anak. Bila orang tua bersikap positif kepada anak, berarti orang tua juga bisa berpersepsi positif kepada anak. Begitu pula sebaliknya bila orang tua bersikap negatif kepada anak, dimungkinkan orang tua juga memiliki persepsi negatif juga pada anak, begitu pula sebaliknya antara anak dengan orang tua. Tujuan penelitian adalah untuk mengetahui tipe parenting orang tua yang efektif untuk pencegahan penyalahgunaan narkoba pada remaja. 


\section{METODE PENELITIAN}

Penelitian ini menggunakan rancangan komparatif. Peneliti membedakan parenting orang tua yaitu authoritative parenting, authoritarian parenting dan permissive parenting terhadap upaya mencegah penggunaan narkoba bagi remaja putra dan putri. Penelitian dilakukan di Kecamatan Panji Kabupaten Situbondo, dengan pertimbangan bahwa lokasi tersebut termasuk daerah rawan peredaran narkoba. Penetapan subyek penelitian berdasarkan purposive sampling dengan karakteristik usia 13-19 tahun, berjenis kelamin putra dan putri, hidup bersama dengan semua orang tuanya. Responden penelitian sejumlah 80 subyek untuk grup remaja putra dan 80 subyek grup remaja putri. Data dikumpulkan dengan kuesioner/ angket parenting orang tua yang diukur melalui persepsi remaja. Analisis data menggunakan perhitungan komputer dari paket statistik penelitian dengan Anova yang bertujuan ingin membedakan tipe parenting orang tua (variabel $\mathrm{x}$ ) terhadap upaya mencegah penggunaan narkoba bagi remaja putra dan putri (variabel y).

\section{HASIL DAN PEMBAHASAN}

Peneliti mendapatkan hasil penelitian berupa data dan langsung dilakukan tabulasi. Selanjutnya analisis dilakukan menggunakan aplikasi Anova dengan hasil nilai $\rho=0,022$ artinya $\rho<0,05$ maka ada beda tipe parenting (Authoritative, Autoritarian dan Permissive) terhadap upaya mencegah penggunaan narkoba bagi remaja putra dan putri. Untuk melihat adanya perbedaan yang lebih jelas, dibentuk tabel sebagai berikut:

Tabel 1: Analisa Anova pada data hasil penelitian (A: Grup Putra \& Putri dan B: Parenting Orang tua )

\begin{tabular}{ccccccc}
\hline $\begin{array}{c}\text { A: } \\
\text { Grup Remaja }\end{array}$ & \multicolumn{3}{c}{$\begin{array}{c}\text { A1: Grup Putra } \\
\text { N=80 subyek }\end{array}$} & & \multicolumn{3}{c}{$\begin{array}{c}\text { A2: Grup Putri } \\
\text { N=80 subyek }\end{array}$} \\
\hline B: & 1. & 2. & 3. & 1. & 2. & 3. \\
$\begin{array}{c}\text { Parenting } \\
\text { Orang Tua }\end{array}$ & Authoritative & Autoritarian & Permissive & Authoritative & Autoritarian & Permissive \\
& Mean & Mean & Mean & Mean & Mean & Mean \\
& A1B 13,874 & A1B2=18,624 & A1B3=10,181 & A2B1=17,499 & A2B2=15,166 & A2B3=8,454 \\
\hline
\end{tabular}

Berdasarkan tabel 1 diperoleh informasi bahwa: Authoritative parenting pada grup remaja putra (A1B1) dan grup remaja putri (A2B1), terdapat perbedaan rata-rata antara grup remaja putra $(13,874)$ dan rata-rata pada grup remaja putri $(17,499)$, berarti rata-rata $\mathrm{A} 2 \mathrm{~B} 1(17,499)>$ ratarata A1B1(13,874). Dapat disimpulkan bahwa terdapat perbedaan authoritative parenting pada grup remaja putra dan grup remaja putri dimana orang tua pada grup remaja putri cenderung memberikan authoritative parenting.

Remaja memiliki waktu untuk mengemukakan keberatan di depan orang tua jika tugasnya sangat memberatkan. Untuk grup putri dari 80 subyek, diberi pernyataan dan diberi waktu ada 54 subyek $(67,5 \%)$, diberi pernyataan sedikit diberi waktu ada 18 subyek $(22,5 \%)$ dan yang tidak diberi waktu ada 8 subyek (10\%). Untuk grup putra, dari 80 subyek diberi pernyataan dan diberi waktu 16 subyek (20\%), serta sedikit diberi waktu ada 54 subyek $(67,5 \%)$, berikutnya tidak diberi waktu 10 subyek $(12,5 \%)$.

Remaja mempunyai persepsi bahwa pendapatnya bisa diterima oleh orang tua. Untuk grup putri dari 80 subyek, yang memberi pernyataan bahwa orang tua bisa menerima pendapat anak terdata ada 50 subyek $(62,5 \%)$, orang tua sedikit bisa menerima pendapat anak ada 20 subyek $(25 \%)$ dan orang tua yang tidak bisa menerima pendapat anak ada 10 subyek $(12,5 \%)$. Untuk grup putra, dari 80 subyek memberi pernyataan bahwa orang tua bisa menerima pendapatnya ada 20 subyek (25\%), orang tua sedikit bisa menerima pendapat anak ada 18 subyek $(22,5 \%)$ dan orang tua yang tidak bisa menerima pendapat anak ada 42 subyek $(52,5 \%)$.

Remaja mempersepsikan bahwa orang tua memberi solusi jika mempunyai problem. Dari 80 subyek grup putri, 54 subyek $(67,5 \%)$ memberi pernyataan bahwa orang tua memberi solusi jika anaknya mempunyai problem, 18 subyek $(22,5 \%)$ menyatakan bahwa orang tua sedikit memberi solusi ketika anaknya mempunyai problem dan 8 subyek (10\%) menyatakan bahwa orang tua tidak memberi solusi jika anaknya mempunyai problem. Untuk grup putra, dari 80 subyek, 6 subyek (20\%) menyatakan bahwa orang tua memberi solusi jika anaknya mempunyai problem, 14 subyek $(17,5 \%)$ menyatakan bahwa orang tua sedikit memberi solusi jika anaknya mempunyai problem dan 50 subyek $(62,5 \%)$ menyatakan bahwa orang tua tidak memberi solusi ketika anaknya mempunyai problem. 
Authoritative parenting cenderung diberikan oleh orang tua untuk grup putri, kriteria orang tua yang mempunyai sikap authoritative antara lain: (a) bila anak menjalankan kegiatan atau beraktifitas, ada penjelasan dari orang tua untuk apa menjalankan hal tersebut; (b) hukuman bisa diterima setelah anak ada ruang waktu untuk menjelaskan mengapa peraturan itu dilanggar; (c) pemberian hukuman sesuai dengan tingkat pelanggarannya; (d) bila anak mempunyai prestasi orang tua memberikan penghargaan. Orang tua dalam authoritative parenting bukan membuat aturan semena-mena di depan anak-anaknya, namun orang tua selalu mempunyai penjelasan mengapa peraturan diadakan. Sikap authoritative orang tua ditunjukkan dengan selalu adanya penghargaan bila anaknya berbuat baik. Authoritative parenting sifatnya memberikan pilihan bebas di depan anaknya dengan syarat masih adanya kontrol atau pengawasan dari kebijakan orang tua. Pengambilan keputusan selalu dengan dasar musyawarah dengan anak untuk melakukan keputusan bersama. Anak selalu diberi ruang waktu cukup untuk menyampaikan pendapatnya dengan sikap saling menghargai pendapatnya masing-masing.

Hasil penelitian Djamarah Syamsul Bachri (2014), anak yang berada di lingkungan authoritative parenting bisa mempunyai kebiasaan melakukan sosialisasi dengan baik. Authoritative parenting bisa mempunyai sifat kebersamaan dengan teman-teman yang lain dan bisa bekerja sama di depan semua familinya. Authoritative parenting merupakan pengasuhan dimana orang tua dekat, bersahabat dan perhatian kepada anak. Orang tua memberi kesempatan kepada anak untuk mengutarakan pendapat atau pemikirannya terutama untuk menyelesaikan masalah. Terdapat kebebasan walaupun terbatas terhadap pilihan yang terbaik sesuai kehendak anak seperti pemikiran, diskusi, dan pola hidup pribadi anak. Orang tua memberi kesempatan kepada anak untuk berkembang terhadap kontrol dirinya sendiri dan untuk berlatih bertanggung jawab kepada keputusan dan tindakan yang diperbuatnya. Orang tua dengan authoritative parenting memberi kesempatan kepada anak-anaknya untuk merasa dihargai dan diberi kebebasan untuk mengungkapkan apa yang terasa di hatinya, merasa diperlakukan sama dengan saudara-saudaranya serta diberi hak-hak, kewajiban yang tepat sesuai dengan kemampuan masing-masing. Orang tua paham terhadap ciri khas tumbuh kembang untuk remaja pada tahapan usianya dan cara bagaimana untuk memperlakukan remaja, membimbing serta mengarahkan remaja yang mempunyai talenta. Orang tua dengan authoritative parenting bisa mengerti tahapan perkembangan psikologis anak, paham self emotion serta memberi kesempatan kepada anak untuk menyampaikan apa yang diinginkan. Orang tua juga bisa memberikan arahan dan dukungan ke arah yang benar, sehingga bisa mendukung untuk sosialisasi terutama menuju kemampuan berprestasi.

Authoritarian Parenting pada grup remaja putra (A1B2) dan grup remaja putri (A2B2), menunjukkan ada perbedaan rata-rata antara grup remaja putra $(18,624)$ dan rata-rata pada grup remaja putri $(15,166)$, berarti rata-rata A1B2 $(18,624)>$ rata-rata A2B2 $(15,166)$. Hal ini membuktikan terdapat perbedaan antara authoritarian parenting untuk grup putra dengan grup putri, yaitu orang tua untuk grup putra cenderung memberikan authoritarian parenting.

Analisis tersebut bisa didukung dengan data penelitian dari subyek yaitu: Remaja mempersepsikan keputusan dari orang tua tidak mutlak. Untuk grup putri, dari 80 subyek yang mengutarakan bahwa keputusan orang tua fleksibel ada 50 subyek $(62,5 \%)$, yang mengutarakan bahwa keputusan orang tua sedikit fleksibel ada 18 subyek (22,5\%) dan 12 subyek (15\%) mengutarakan bahwa keputusan orang tua tidak fleksibel. Untuk grup putra, dari 80 subyek yang mengutarakan bahwa keputusan orang tua fleksibel ada 8 subyek (10\%), selanjutnya 16 subyek (20\%) mengutarakan bahwa keputusan orang tua sedikit fleksibel dan 56 subyek (70\%) mengutarakan bahwa keputusan orang tua tidak fleksibel.

Remaja mempersepsikan tidak diberi waktu dalam mengemukakan alasan kesalahannya ketika menerima hukuman dari orang tua. Untuk grup putri, dari 80 subyek yang mengemukakan pemberian hukuman orang tua dengan diberi waktu untuk menjelaskan problemnya terdata 10 subyek $(12,5 \%)$, yang mengemukakan pemberian hukuman orang tua dengan sedikit diberi waktu dalam menjelaskan problemnya terdapat 14 subyek $(17,5 \%)$ dan 56 subyek (70 \%) mengemukakan pemberian hukuman dari orang tua tanpa diberi waktu untuk menjelaskan penyebab kesalahan.

Untuk grup putra, dari 80 subyek yang mengemukakan bahwa hukuman diberikan orang tua tanpa diberi waktu untuk menjelaskan penyebab kesalahan terdapat 52 subyek $(65 \%), 14$ subyek $(17,5 \%)$ mengemukakan bahwa hukuman diberikan orang tua dengan sedikit diberi waktu untuk menjelaskan problemnya dan 14 subyek $(17,5 \%)$ mengemukakan bahwa hukuman 
diberikan oleh orang tua dengan diberi waktu untuk menjelaskan penyebab kesalahan.

Remaja mempersepsikan orang tua memutuskan adanya kegiatan yang mutlak harus dilakukan. Untuk grup putri, dari 80 subyek yang mengutarakan aktivitas anak diputuskan orang tuanya dengan fleksibel terdapat 26 subyek $(32,5 \%)$, yang mengutarakan aktivitas anak diputuskan orang tuanya dengan sedikit fleksibel ada 8 subyek (10\%), aktvitas anak diputuskan orang tuanya dengan tidak fleksibel terdapat 46 subyek $(57,5 \%)$. Untuk grup putra, dari 80 subyek yang mengutarakan aktivitas anak ditentukan orang tua dengan fleksibel terdapat 18 subyek $(22,5 \%)$, sedikit fleksibel ada 12 subyek (15\%) dan yang mengutarakan tidak fleksibel ada 50 subyek $(62,5 \%)$.

Orang tua untuk grup putra cenderung menggunakan authoritarian parenting. Hal ini ditunjukkan dengan sikap authoritarian orang tua yaitu: (a) orang tua selalu mengatur anak dan tidak ada pemberitahuan terhadap masalahnya; (b) jika remaja sudah melakukan kesalahan dan sudah ditentukan, anak tidak diberi waktu untuk memberi alasan dari sebelumnya terhadap hukum yang diterima anak; (c) untuk hukuman secara umum dengan bentuk fisik atau raga; (d) orang tua tidak atau sedikit memberi penghargaan baik dalam wujud kalimat atau wujud lainnya, jika anak melakukan sesuai dengan keinginginan orang tua. Parenting yang didasari dengan aturan yang kaku, salah satunya orang tua memberi aturan kepada anak tanpa menjelaskan alasan mengapa aturan tersebut diberikan. Anak-anak dari orang tua authoritarian selalu merasa bahwa untuk berperilaku dan melakukan peraturan yang diberikan untuk diri sendiri tidak ada kesesuaian dengan keinginannya, walaupun begitu anak tidak bisa membantah. Akhirnya terjadi kesalahan ketika anak berada di luar rumah yang mengarah pada kenakalan dan bisa mengarah pada gangguan psikologis. Authoritarian parenting bisa sebagai pendukung untuk berperilaku keras di luar keluarganya karena merupakan pengalihan dari kekecewaan pribadi akibat dari pengasuhan yang keras sebelumnya (Yaumi, 2014). Sebagian anak berperilaku sedikit kreatif dan pasif, sering membantah, sering berkelahi, kurang ada rasa tanggungjawab masalah ini terjadi karena sering adanya penampilan dominasi orang tua di depan anaknya.

Menurut Naim (2012), dalam authoritarian parenting anak harus bisa menuruti keinginan orang tua, sehingga anak menjadi pasif, pendiam, ragu-ragu pemalu dan tidak mandiri serta berperilaku menarik diri dari lingkungan (Vermeulen-Smit E, Verdurmen JE, Engels RC, 2015). Authoritarian parenting merupakan pola pengasuhan dengan sifat dan peraturan yang keras dan kaku. Dalam hal ini orang tua cenderung memaksakan kehendaknya. Asuhan ini berperilaku mendikte kemauan anak, perilaku bebas sangat dibatasi dan dikendalikan oleh orang tua. Komunikasi antara orang tua dengan anak sering terjadi hanya satu arah, anak jarang diajak diskusi, serta tidak ada tukar pemikiran dengan orang tua. Anak juga jarang diberi kesempatan untuk mengutarakan pendapatnya dan bila melakukan kesalahan pasti diberi hukuman yang berat. Anak tidak diberi kesempatan untuk memberi penjelasan.

Permissive parenting untuk grup putra (A1B3) dan grup putri (A2B3), memperlihatkan ada perbedaan rata-rata antara grup putra $(10,181)$ dan rata-rata untuk grup putri $(8,454)$, artinya ratarata A1B3 $(10,181)>$ rata-rata A2B3 $(8,454)$. berarti terdapat perbedaan parenting orang tua permissive untuk grup putra dan grup putri, yaitu orang tua untuk grup putra cenderung permissive parenting.

Analisa tersebut bisa didukung dengan data hasil penelitian yaitu remaja mempersepsikan bahwa anak mendapatkan kebebasan memilih secara penuh oleh orang tuanya. Untuk grup putri, dari 80 subyek yang mengemukakan bahwa mereka mendapatkan kebebasan memilih ada 14 subyek $(17,5 \%)$, sedikit mendapatkan kebebasan memilih ada 26 subyek $(32,5 \%)$ serta yang tidak mendapatkan kebebasan memilih ada 40 subyek (50\%). Untuk grup putra, dari 80 subyek yang menyatakan bahwa mereka mendapatkan kebebasan memilih ada 48 subyek $(60 \%)$, sedikit mendapatkan kebebasan memilih ada 22 subyek $(27,5 \%)$ dan tidak mendapatkan kebebasan memilih 10 subyek (12,5\%).

Remaja mempersepsikan bahwa anak belum ada tuntutan dari orang tuanya. Untuk grup putri, dari 80 subyek, yang mengemukakan bahwa orang tuanya belum ada tuntutan untuk anaknya ada 24 subyek (30\%), orang tuanya ada sedikit tuntutan untuk anaknya ada 40 subyek (50\%) dan 16 subyek (20\%) menyatakan bahwa orang tuanya ada tuntutan untuk anaknya . Untuk grup putra, dari 80 subyek, yang mengemukakan orang tuanya belum ada tuntutan untuk anaknya 48 subyek $(60 \%)$, orang tuanya sedikit ada tuntutan untuk anaknya ada 18 subyek $(22,5 \%)$ dan orang tuanya ada tuntutan untuk anaknya 14 subyek $(17,5 \%)$.

Remaja mempersepsikan bahwa anak diberikan kebebasan memilih untuk menentukan kegiatan oleh orang tuanya. Untuk grup putri, dari 
80 subyek yang mengutarakan bahwa orang tuanya memberikan kebebasan memilih dalam menentukan kegiatan untuk anaknya ada 26 subyek $(32,5 \%)$, orang tuanya sedikit memberikan kebebasan memilih dalam menentukan aktifitas untuk anak terdapat 30 subyek $(37,5 \%)$ serta yang mengutarakan orang tua tidak memberikan kebebasan memilih dalam menentukan kegiatan untuk anaknya ada 24 subyek (30\%). Untuk grup putra, dari 80 subyek yang mengutarakan orang tuanya memberikan kebebasan memilih dalam menentukan kegiatan untuk anaknya terdapat 50 subyek $(62,5 \%)$, orang tua sedikit memberikan kebebasan memilih dalam menentukan aktifitas untuk anak ada 18 subyek $(22,5 \%)$ dan orang tua tidak memberikan kebebasan memilih dalam menentukan aktifitas untuk anak terdapat 12 subyek $(15 \%)$.

Grup putra cenderung mendapatkan permissive parenting dari orang tuanya. Menurut (Lestari, I., 2014), sikap permissive orang tua mempunyai kriteria sebagai berikut: (a) orang tua tidak memberikan aturan, semua perbuatan yang diinginkan anak boleh dilakukan; (b) tidak perlu sanksi, sebab tidak ada aturan atau peraturan yang dilanggar; (c) akibat kesalahan dianggap akan menjadi sebuah hal biasa.

Authoritarian parenting dianggap sebagai kebalikan dari permissive parenting, anak tidak perlu dikontrol oleh orang tuanya. Kemungkinan anak mendapat kepuasan dalam kehidupan sosialnya dan anak merasakan sendiri dampak dari perbuatan yang dilakukan. Orang tua membiarkan anak berbuat segalanya sesuai dengan keinginannya tanpa adanya peraturan, bimbingan, arahan dan pendidikan. Untuk permissive parenting, orang tua sangat melindungi dan menyayangi anaknya, sehingga anak kesulitan beradaptasi dengan kondisi di luar rumah, sering menuntut, ketergantungan, ingin menang sendiri, sering marah, resah, tidak bisa mandiri, emosional, mementingkan diri sendiri, cerewet dan labil.

$$
\text { Permissive parenting merupakan }
$$

pengasuhan yang berciri khas memberi kebebasan kepada anak, karena anak dianggap sebagai orang dewasa yang masih muda. Orang tua memberi model secara longgar kepada anak untuk melakukan kegiatan tanpa harus ada peraturan dari orang tuanya. Dalam hal komunikasi, anak diberi kebebasan untuk mengeluarkan pendapat dan idenya secara luas. Anak diberi kesempatan oleh orang tua dalam melaksanakan keinginannya tanpa ada kendali dari orang tua. Orang tua jarang memberi pengawasan terhadap apa yang dilakukan oleh anak.
Kontroling yang dilaksanakan oleh orang tua kepada anak jarang dilaksanakan. Selain itu, orang tua juga jarang memberi tuntunan yang mendidik kepada anak. Apa saja yang diperbuat oleh anak tidak ada yang salah dan tidak perlu dikoreksi. Semua hal dianggap sesuai dengan kebenaran karena anak anak masih dalam usia belia. Sehingga hal semacam ini dianggap sebagai kewajaran yang bisa menjerumuskan anak remaja ke arah penyalahgunaan narkoba. Selain faktor parenting, ada juga pengaruh lain yang bisa mendukung subyek untuk menggunakan narkoba seperti faktor eksternal yaitu lingkungan masyarakat, dan lingkungan anak di luar (Hadriansyah, 2014). Namun ada juga pengaruh lain yang bisa membuat subyek menggunakan narkoba seperti kondisi sekitar sekolah dan orang dekatnya (Badan Narkotikaa Nasional, 2013).

Berbekal dari lingkungan keluarga, maka anak akan memiliki modal tentang cara paling dasar yang sangat penting. Dimulai dari lingkungan keluarga yang baik maka akan memudahkan anak bersosialisasi dengan lingkungan di luar. Baik tidaknya sosialisasi dengan lingkungan di luar sangat tergantung bekal awal yang didapatkan dari lingkungan keluarga. Lingkungan keluarga dan lingkungan di luar keduanya membentuk perkembangan anak remaja.

$$
\text { Perkembangan kepribadian dan }
$$
pembentukan karakter remaja diawali dari lingkungan keluarga. Budaya dan kebiasaan baik akan dibawa oleh remaja ketika bergaul dengan teman-teman sebayanya di luar lingkungan keluarga. Bila remaja sudah berada di luar lingkungan keluarga dan mampu membawa serta mempertahankan budaya dengan kepribadian dari lingkungan keluarga yang baik, maka mereka tidak akan terpengaruh oleh teman-teman sebayanya dengan kepribadian dan karakter berbeda-beda. Terjadinya kenakalan remaja hingga akhirnya terjerumus ke arah penyalahgunaan narkoba pada umumnya diakibatkan karena remaja tidak mampu mempertahankan kepribadian dan karakter baik yang sudah ditanamkan dari keluarga dan mudah dipengaruhi oleh teman bermainnya. Menurut Murtiyani (2011) dalam penelitiannya, kebanyakan remaja pengguna zat terlarang tersebut menduga bahwa orang tuanya terlalu mempermasalahkan dan selalu mencampuri urusan anaknya. Orang tua selalu merasa berkuasa atas diri anak sehingga seorang anak harus patuh dan mengikuti apa kata orang tua serta sering mempermasalahkan apa yang dilakukan oleh anak. Kebalikan dari anak yang tidak menyalahgunakan narkoba, anak menganggap bahwa orang tua menjadi motivator 
untuk aktif dalam kegiatan di lingkungan sosial remaja serta oang tua mendorong anak untuk bisa mandiri, kreatif dan inovatif.

\section{KESIMPULAN DAN SARAN}

Ada perbedaan dalam upaya pencegahan penggunaan narkoba yang berhubungan dengan parenting orang tua untuk grup putra dan grup putri, dimana teridentifikasi bahwa untuk grup putra mempunyai keterkaitan dengan authoritarian dan permissive parenting. Saran bagi orang tua agar dapat memberikan authoritative parenting seperti: memberikan penjelasan dan pengertian jika anak harus melakukan aktivitas tertentu, memberikan kesempatan kepada anak untuk mengemukakan alasan terkait pelanggaran yang telah dilakukan, memberikan hukuman sesuai dengan kapasitas pelanggaran yang dilakukan, memberikan penghargaan dan pujian. Semua ketentuan yang dilaksanakan merupakan kesepakatan antara anak dengan orang tua sehingga tercipta kebahagiaan, keamanan, kesenangan dan kesejahteraan.

\section{REFERENSI}

Abdullah, N. (2015) 'Hubungan Parenting Orang Tua dengan Konsep Diri Anak Usia Sekolah', Jurnal Psikologi Forum UMM. Malang, 5(1), pp. 222-225.

Adpriyadi 1 \& Sudarto 2 (2018) 'Parenting Orang tua dalam Pengembangan Potensi Diri dan Karakter Anak Usia Dini', Jurnal Ilmiah Ilmu Pendidikan Persada Khatulistiwa Sintang, 11(1), pp. 26-38.

Anisah (2011) 'Parenting orang tua dan implikasinya terhadap pembentukan Karakter anak', Jurnal Pendidikan Universitas Pendidikan Garut, 05(01), pp. 70-84.

Badan Narkotika Nasional (2017) 'Hasil Survey Nasional Penyalahgunaan dan Peredaran Gelap Narkoba pada Kumpulan Putri Dan Maharemaja di 33 Propinsi di Indonesia.', pp. 18-25.

Badan Narkotikaa Nasional (20113) 'Pencegahan Penyalahgunaan Narkoba sejak Usia Dini', p. 15.
Djamarah Syamsul Bachri (2014) 'Parenting Orang Tua dan Komunikasi dalam Keluarga: Upaya Membangun Citra Membentuk Pribadi Anak, (Jakarta: Rineka Cipta,)', p. 1.

Hadriansyah (2014) 'Pengetahuan Dan Sikap Keluarga Dalam Upaya Pencegahan Penyalahgunaan Narkoba Pada Remaja Di Desa Seuleukat Kecamatan Bakongan Timur Kabupaten Aceh Selatan', pp. 149-202.

Lestari, I., D. (2014) 'Hubungan Pengetahuan, Sikap Remaja dan Pekerjaan Orang tua tentang Narkoba pada Remaja SMA Negeri 1 Takalar', Jurnal Ilmiah Kesehatan Diagnosis, 5(2), pp. 117-122.

Matejevic M, Jovanovic D, L. V. (2014) 'Functionality of family relationships and parenting style in families of adolescents with substance abuse problems', in procedia Soc Behav Sci, p. 128: 281.

Murtiyani N (2011) 'Hubungan Parenting Orang Tua dengan Kenakalan Remaja di RW V Kelurahan Sidokare Kecamatan Sidoarjo', Jurnal Keperawatan, 1(1), pp. 1-9.

Naim, N. (2012) 'Character Building: Optimalisasi Peran Pendidikan dalam Pengembangan Ilmu \& Pembentukan Karakter bangsa', p. 13.

Rabinowitz JA, Drabick DA, Reynolds MD, Clark DB, O. T. (2016) 'Child temperamental flexibility moderates the relation between positive parenting and adolescent adjustment', J Appl Dev Psychol, 12(8), pp. 43-53.

Sweeney CT, Sembower MA, Ertischek MD, Shiffman S, S. S. (2013) 'Nonmedical use of prescription ADHD stimulants and preexisting patterns of drug abuse.', Journal of Addictive Diseases, 3(2), pp. 1-10.

Vermeulen-Smit E, Verdurmen JE, Engels RC, V. W. (2015) 'The role of general parenting and cannabis-specific parenting practices in adolescent cannabis and other illicit drug use', pp. 147-222.

Yaumi, M. (2014) 'Pendidikan Karakter Landasan, Pilar, dan Implementasi’, p. 3. 